\title{
Developing Career through Community Engagement: The Nigerian University Experience
}

\author{
Samuel Olutokunbo Adekalu*, Ismi Arif Ismail, Steven Eric Krauss, and Turiman Suandi \\ Department of Professional Development and Continuing Education, Faculty of Educational Studies, Universiti Putra Malaysia \\ Corresponding author: Samuel Olutokunbo Adekalu, E-mail: adekaluolutokunbo@gmail.com
}

\section{ARTICLE INFO}

Article history

Received: October 16, 2017

Accepted: July 29, 2018

Published: July 31, 2018

Volume: 6 Issue: 3

Conflicts of interest: None

Funding: None

\begin{abstract}
So far, there has been no serious correction awareness aimed at addressing and promoting career development through community engagement practice in Nigeria, especially in academic settings. No research has been carried out to examine faculty members, particularly professors' experiences in developing career through community engagement activities in the Nigerian universities. To address this gap, this article presents the perspectives of professors on how faculty members can be attracted to community engagement as a strategy to develop career and boost the reputation of their respective institutions that has been dominated by teaching and research. This article employed the qualitative method, interviewing nine professors from diverse academic disciplines in a leading conventional university in Nigeria. From the analysis, community engagements were found to foster academic career development of the professors in their areas of expertise. More specifically, participatory community engagement outreach helped in expansion of knowledge through solving practical problems, career growth through promotion earned, and increased job satisfaction. The study concludes with implications for human resource development practice and suggestions for future research.
\end{abstract}

Key words: Career Development, Community Engagement, University Professors, Nigeria

\section{INTRODUCTION}

In African context and particularly in Nigeria, institutions of higher education are yet to link up with the community due to globalization and its challenging attributes. This is because the contribution of African academics to research and global discussion has been found to be abysmally low (Adams, 2010; Akinyemi \& Potokri, 2016; Akpan, Archibong \& Undie, 2011, Idowu, 2014). Research in enhancing career development through community engagement activities specifically among academics in universities still lacks the opportunity to generate unique stands in most African literature; however, the global community has been able to learn about Africa through the works of African researchers (Adekalu, Shuti, Turiman, Olohungbebe \& Adio, 2017a; Idowu, 2014; Ifedili \& Ifedili, 2015).

Community engagement in academia is often crucial for faculty members to gain practical work experience in sustaining work-related identities and, in turn, career development. According to Werder and Desimone (2011), career development is defined as a set of activities through which individual determines appropriate personal and professional goals and works to obtain the required skills and experience necessary to obtain those goals. Community engagement represents the various ways in which academics engage with communities, together with research and teaching to promote economic, environmental and socio-cultural develop- ment. Driscoll (2009) refers to community engagement as collaboration between higher education institutions and their larger communities.

Research has shown that being promoted to the professorship cadre is not the ultimate destination of an academic career, rather a means to continue with one's profession and to be self-reliant of one's ability (Adekalu, Krauss, Turiman \& Ismail, 2017b; Maimunah \& Rosiah, 2006; Ismail, 2005; Terosky, 2005). In academia, professors are acknowledged as most influential and leaders in their area of expertise (Adekalu et al., 2017b; Ismail, 2005; Ismail, Silong, Asimiran \& Hassan, 2011; Safiah, Mohd-Taib, Norliah \& Mahadi, 2012). Professors are mostly engaged in formal organizations like institutions of higher learning, ministries, government agencies and corporate organizations; in spite of their other commitments in the form of teaching, research and scholarship (Boyle \& Sawyer 2010; Terosky, O’Meara \& Campell, 2014). It is assumed that engagement in knowledge sharing through community outreach, together with teaching and research positively affects some professors' career (Adekalu et al., 2017b; Ismail, 2005; Maimunah \& Rosiah, 2006; Terosky, 2005; Tight, 2002)

The promotion guidelines to improve human resource capacity and career development of academics in Nigerian institution of higher learning include active participations in community service. Unfortunately, due to lack of institutional supports, academics seem to shy away from devel- 
oping career through participation in community activities. They focus mainly on teaching and research that fall within the universities. This is because emphasis is placed on teaching and research contributions as requirement for promotion in academic profession in Nigeria, while not much effort is committed to community service (Akpan, Archibong \& Undie, 2011, Ifedili \& Ifedili, 2015; Adekalu et al., 2017a). In this study, community engagement is perceived as a means of career development within context of academic profession.

Research has shown that academics in their area of expertise often get involved in community engagement believing they can earn some awards and recognitions, together with research and teaching experience to facilitate promotion (Boyte, 2004; O’Meara, 2002). For example, study carried out by Boyer (1996) among faculty exemplars revealed that they did view community engagement as fountain of intellectual expansion, rather than a secondary type of research. These studies found that through community engagement, faculty members were able to apply their theoretical knowledge in solving practical problems of communities. Also in the process of engagement they realized that there was need for them to reinforce their teaching materials based on the problems which they identified in the community that cannot be solved by the pre-designed plan that was theory-based (Boyer, 1996). In addition, by involving in community engagement faculty members are able to improve their teaching, knowledge, and skills.

The passion to develop academic career through community engagement and choice of lecturing in the university by academics in the past was eroded by the love for money, dishonesty and unethical conducts which is now widely embraced in Nigeria (Ogu, 2008; Utile, 2008; Yusuf, Adebowale, Fagbamigbe, Bamgboye \& Oyediran, 2010). This non-exemplar approaches in developing career through community engagement practice among academics has also led to nonchalant attitude of most Nigerian students in participating in community activities (Ifedili \& Ifedili, 2015), which invariably affects most Nigerian graduates to lack the necessary knowledge, skills, right attitude and drive for promoting community work to enhance the human resource development of the nation. Research that raises issues on university community engagement is growing; a lot of writing tends to be concerned primarily with exploring the engagement of students in community service (Akpan, Archibong \& Undie, 2011, Ifedili \& Ifedili, 2015). Very few studies have been conducted on the career experiences of academics particularly among university professors (Adekalu et al., 2017b; Ismail, 2005; Ismail et al., 2011; Safiah et al., 2012) while little or no empirical research on this topic is available in the Nigerian context.

Clear evidence is seen in a study that Ifedili and Ifedili (2015) recently conducted in 27 federal universities in Nigeria, on what is hindering university management from making community engagement practice operative, as it is practiced in developed countries where faculty members and students see it as a pride to contribute towards development of the community. The study revealed that $69 \%$ of university academics staff and $83 \%$ of students did not get involved in community engagement. Out of the study population, $78 \%$ of students as opposed to $82 \%$ of faculty members had positive attitude towards rendering community service while $94 \%$ of those who rendered voluntary service to the community were not motivated. Additionally, $60 \%$ of both faculty members and students further revealed that the university management neither organized nor developed strategic plan for community engagement as expected. In the opinion of Bako (2005), over 99.5\%, if not all, of activity and time of the Nigerian academics are devoted to teaching and assessing students throughout the year, without definite official time designated for doing research and service to the community. This is because, the idea of career development through community engagement outreach and research as custom in academic activity for generating knowledge for economic development has not yet dawned on the Nigerian ruling class, policy makers, and university faculty members (Adekalu et al., 2017a).

The World Health Organization (2002) noted that through community engagement skills are developed and competencies are built, with new opportunities for innovative thinking and development. Likewise, the New Economy Development Group (2002) noted that it is only through community engagement that people develop the skills and acquire the knowledge which is required for solving real world problems. Past studies revealed that for one to acquire knowledge, experiences and skills required for solving real world problems, one must be willing to be involved in community engagement. In the opinion of the authors, being able to solve real world problems is an indicator of professional growth, if not its height.

Most of the work on Nigerian academic staff engagement in community service has been based on self-opinion. No research has been carried out to examine how faculty members, particularly Nigerian professors, develop academic career through engagement in community work.

\section{Objective and Research Question}

The present study examines how community engagement boosts career development among university professors. While reflecting on current practices, experiences, challenges, expectation and opportunity related to teaching, research and services for human resource development, the study set to answer one singular research question:

- How does community engagement contribute to academic career development?

\section{THE CURRENT STUDY}

Community engagement usually serves as a strategy that focuses on the career and human capacity development of faculty member in higher education (Neuman 2000; Metha, Gorski, Liu, Weinstein, Brua \& Christensen, 2015). Discourses of community engagement among academics revealed that those who engage in community development activities often report incredible professional and personal growth (Kogan \& Teichler, 2007; Terosky et al., 2014; 
Adekalu et al., 2017b). This is because through community engagement outreach, faculty members are able to have the knowledge and experiences, and practical skills required for career growth, competencies development and professionalism. In the current study, it is hypothesised that through community engagement, research and teaching, the capacity of the faculty members is built. Implying that community engagement contributes to the development of human resources in higher education institutions, because it serves as a training ground where faculty members are able to acquire new knowledge and skills which enhance their research and teaching roles. Academics are expected to improve their teaching skills by being able to link theory and practice through their experience with real world situations in their engagement in community service. In this study, community engagement is perceived as a means of career development within context of academic profession. Academics in institutions of higher learning in Nigeria seem to teach and engage in research without advantage of community service to boosting academic career development. This study aims to generate unique stands to the career development and community engagement in higher education literature by sharing the career development and community engagement of university professors' in Nigeria.

\section{METHODS}

This study adopted a descriptive survey utilising qualitative approaches to include the data from participant observations, case study, and in-depth semi-structured interviews (Das, 1983). The qualitative data consist of interview transcripts, observations from the researchers, detailed descriptions from case study, field notes, and documents and academic and professional journal publications (Patton, 2002).

Purposive sampling method was used in selecting nine university professors involved in community engagement. This technique allows the researchers to choose specific samples that provide insights into the issues related to the study area (Alston \& Bowles, 2003).

Some criteria were used for selection of the study participants; they had to be university full professors, have University/College Bachelor degree, have University/College Master degree, have Doctor of Philosophy (PhD) or equivalent degrees from local or foreign government approved or recognized institution, have at least 15 years of work experience in academic profession, have sufficient experience and regular engagement in community service, have received recognitions and awards within and outside of the university for community engagement activities in their respective fields of study, and be acknowledged by the university authorities.

The study data were obtained at the Kwara State University, Malete. The university was approved by Kwara State Government as a university with a reputation for excellence in teaching, research and community interventions.

Nine professors from nine different academic backgrounds and career experiences in community engagement activities were explored at the Kwara State University. The participants were selected from the College of Agriculture, Applied Sciences, Education, Engineering, Humanity, In- formation Communication Technology, and Social Sciences. Among the nine participants, seven were males and two were females. The age of the participants ranged from early 40 s to early 70 s, the average age being in the late 50 s. They all had more than 15 years of work experience in academia. Within the sample, three of the professors obtained their doctoral degrees in Nigeria, while the remaining six acquired them from overseas institutions.

Each participant was interviewed between 1 and 4 times throughout the study. Each interview lasted approximately 20 minutes to 2 hours. A total of 19 one-on-one interviews were conducted. Documentary review was carried out during fieldwork when no interviews were being carried out. The documents were reviewed to support the data collected through interviews, participant observation, memos and field notes. Table 1 shows details of the professors who participated in the research.

\section{RESULTS}

The answers provided by the professors indicated the participants' similar and different views. Three major themes emerged from the various categories extracted from the interviews held with the participants. In order to derive the three major themes, the categories which were extracted were critically examined in order to find out the similarities between the different categories; related categories were merged to form major themes. The extracted themes are; career growth through promotion earned by community engagement, expansion of knowledge and work scope through solving practical problems, and job satisfaction as a result of community engagement.

\section{Career Growth through Promotion Earned by Community Engagement}

One of the major contributions community engagements outreach has made to academic career development is promotion at work. The professors explained that the university had made it a criterion for promotion by allocating $20 \%$ to community engagement when considering lecturers for promotion. However, some of them expressed that the role community engagement plays in the promotion they get at work is minimal because it is not a key performance indicator; it is just one of the criteria for promotion; as participant PK4 explained:

In this university, community engagement is one of the things considered for promotion; you are not given very high marks but it's one of the criteria. Community engagement is present in every university in Nigeria but does not carry much weight like publishing research papers.

Majority of the participants indicated that they earned their promotions through their academic activities such as paper publications and performance in classroom activities which were their primary roles.

Participant PK6 further stressed the fact that community engagement was a criterion for promotion even though research paper publication was the most important criterion which was considered during promotion; as he said: 
Table 1. Research participants, college, area of expertise and gender

\begin{tabular}{llll}
\hline Participants & College & Area of expertise & Gender \\
\hline PK1 & Agriculture & Plant bridging and genetic & Male \\
PK2 & Education & Sport Management & Male \\
PK3 & Agriculture & Agricultural extension & Male \\
PK4 & Engineering & Soil and Water & Male \\
PK5 & Humanity & Gender and English literature & Female \\
PK6 & Humanity & Linguistics & Female \\
PK7 & Applied science & Geology & Male \\
PK8 & Social science & Political science & Male \\
PK9 & ICT & Computer science & Male \\
\hline
\end{tabular}

I tell my staff, remember, for promotion you have to do some community work, so go out and reach out because that is part of promotion assessment. Even though publication is the most important, if you don't engage in community service you will be asked why you haven't done so. So, I make it part and parcel of my work.

Despite this, participant PK3 still emphasised on the importance of community engagement in career growth of professors as he strongly stated that:

You cannot be a professor or even a senior lecturer without community engagement; people have to assess the impact that you have made in the community. This constitutes about 20\% when you are being assessed for promotion. So you have to provide evidences of what you have done for the community; they should see evidences not only publication. Your community work must be seen not just stories.

Similarly, participant PK2 shared the same view with participant PK3 saying:

Here in KWASU the criterion for promotion is essentially the same as all universities around the world; there may be some differences in emphasis placed on some criteria used for promotion. Here in KWASU for example the criterion for promotion which is highly emphasised is community outreach and if you don't meet this requirement then you don't get promoted. You must be able to say within 2-3 years while waiting for promotion, what you have done, what you have used your expertise and knowledge for, whether as an individual or as a member of a group. If you don't have this in KWASU you will not be promoted because it is a standard rule.

In the same vein of the contribution of community engagement to career growth and development, one of the participants expressed a different view saying that community engagement serves as curriculum vitae booster. This participant stated that it contributes to career development because it can assist one in getting an appointment within and without the academic environment; as he expressed:

Well, in terms of career development, whatever project you do becomes part of your $\mathrm{CV}$; it will boost your $\mathrm{CV}$ and that is part of career development. People will be able to see on your $\mathrm{CV}$ that this is what you have done and that will make you different from others when you are looking for an appointment.
Majority of the study participants indicated that community engagement in KWASU contributes to their career growth through promotion while others had different views. However, they expressed that the contribution of community engagement to the career growth through promotion is insignificant but important as it makes up $20 \%$ of the promotion assessment.

\section{Expansion of Knowledge and Work Scope through Solving Practical Problems}

Some of the participants indicated that through their engagement in community service their knowledge expands because they do not just focus on the theoretical aspect of their specialization but are also able to link theory and practice by applying theory in solving practical problems of the community. Some of them explained that through community engagement they were able to link practical issues with theory which they teach their students in class; the professors were exposed to practical issues outside the classroom through engagement. Participant PK9 stated that there are some things which they do not learn in school rather they learn on the job through community services and this he said expands his knowledge; he said:

You know there are certain things in academic that there is no school for them but learn on the job. For example, who teaches you how to review paper? When we are given the task of a reviewer, who tells us our task as reviewers? When you are given a paper you do it to the best of your ability. So, you learn on the job; for me it expands your horizon. This expansion of knowledge helps you to know new things and keep expanding the scope of your work.

Furthermore, participant PK2 expressed a similar view to the one above saying that engagement in community service can sustain a professor's academic career because getting involved in community service can boosting one's area of research activities; he stated:

If you get involved as an academic usually you get recognized in a particular area of research, as a professor of sport management, my research focus may not be same as yours but the community development activities I engage can boost my area of research interest. So in that way whatever you are doing is also giving leverage to sustain academic career definitely.. 
Another participant who was a political science professor expressed when he engaged in community service, people from the community asked him different questions related to politics, so he brought back such practical questions to the class and asked his students in order to stimulate their thinking. This, he said improved his teaching method. $\mathrm{He}$ was able to relate practical issues from outside the classroom with theory which is taught inside the classroom.

In like manner participant PK5 indicated that community engagement can expand one's knowledge to have better understanding and solutions to issues in one's research area. She explained and narrated her story saying:

Community engagement is very important to the academia; it's very important because an intellectual has the capacity and the intelligence to diversify and make his/her self-relevant to pragmatic functional ways. Some intellectuals focus on a narrow area of research that are very academic but we must allow academic research to have an output that can cause positive changes that can influence social change in a dynamic way. In my community engagement I have targeted women in many of my researches and that has made me more productive and prolific in writing about women in Nigeria and Africa at large. I have also been able to reach the international community through my writing and publication. In fact, I have been invited by many nations to discuss issues related to the culture, lifestyle, empowerment and challenges of women. This has also made me gain more insight on how to better impact the lives of women. So this is a great impact of community engagement on my academic career.

The responses of the study participants revealed that community engagement has contributed to the growth and development of their academic career significantly because community engagement broadens their knowledge and job scope. They explained that they had been able to have better understanding of issues related to their area of specialization through community engagement thereby having the capacity to give meaningful solutions to problems.

\section{Job Satisfaction as a Result of Community Engagement}

While some of the participants expressed that community engagement had contributed to their academic career through promotion and expansion of knowledge, some others expressed that community engagement gave them a feeling of satisfaction which in turn encouraged them to have the desire to perform better at work. They explained that their participation in community development projects made them feel happy because they did not only focus on themselves but also were able to touch the lives of others. This is described as emotional impact of community engagement. They further explained that being able to make an impact in the lives of others in the community would make the atmosphere conducive to work in because they could not be happy if the people in their community were not happy. Participant PK6 said:

Yes, community engagement outreach has contributed to my academic career because I feel more fulfilled that
I can reach out, that I can help others and that I am not only focusing on myself. So in a way when you feel good about what you are doing, it contributes to your work because you are able to do more; if you are happier you can deliver better service to student, colleagues and so forth. Your overall performance will be better. So, a satisfied professor should impact the lives of others more.

Participant PK4 who expressed the same view as participant PK6 explained that one cannot work well in an environment where other people are unhappy. So it is important to make people in the community happy so that one will enjoy one's working environment. Thus, he stated:

Well, ermm let me start with the psyche, if you live in an environment where every other person is miserable and sad you can't work well, I don't know other people and I am not one of those who sit on a big chair while others sit on the floor; I don't like that. I mean I don't derive any pleasure in that; I can go as far as sacrificing two or three so that we can all have one each. So the satisfaction one gets out of that is important. The little appreciation you get after engaging in community development is enough to make you feel good and do better at work.

Participant PK4 also added that engagement in community development service gives one the experience required to link theory and practice when teaching in class; this improves the quality of teaching skills. He said:

When I was in University of Ife, myself and my late friend (Professor Ogedengbe) first line of engagement was water supply for communities, which we achieved. For example, the dam built at the University of (Ife) we involve in the initial survey. So, if I don't participate in community activities I cannot expect any achievement and if I don't have any achievements I will not be satisfied academically. Many years ago when I started engaging in community engagement activities I started gaining experience from the field; then I will go to deliver lectures in the classroom without books or notes because of the experience I got from the field. It was a very exciting experience which I never had in my teaching career because I didn't have to read too much before giving lectures. I just deliver what is happening in the field real life and connect it to theory. When you involve in community service along with your teaching, it tells positively on your teaching; the quality of your teaching will improve because it is not only theoretical but also practical.

One of the participants added that community engagement can sustain and develop one's academic career if it is carried out in one's area of specialization because professors will be able to link practical issues from the field and theory in class. She also explained that by engaging in community development which is specialization-based, professors will be able to gain new ideas which they can share with their students in the classroom. This participant further stated that when professors engage in community development service they also gain knowledge from the community because without this knowledge they cannot build a good university. This implies that community engagement does not only sustain 
the academic career of the professors but also brings about the development of the entire university. These responses given by the study participants indicate that the community engagement of university professors has a positive impact on their academic career. The contributions which they revealed include promotion at work, expansion of knowledge and job satisfaction.

\section{DISCUSSION}

These responses given by the study participants indicate that the community engagement of university professors has a positive impact on their academic career. Majority of the participants indicated that community engagement in KWASU contributes to their career growth through promotion. However, they expressed that the contribution of community engagement to the career growth through promotion is insignificant as it makes up $20 \%$ of the promotion assessment. This career growth through engagement in community development activities is not just a contribution of community engagement but also a motivator which motivates academics to participate in community development activities as earlier mentioned. This finding supports O’Meara (2008) who also found that community engagement of academics enhances career development. Respondents of the study conducted by O'Meara (2008) indicated that community engagement helps them grow in their career and gives them personal satisfaction. Therefore, it can be said that since this is a personal benefit, it may imply that academics can also be motivated by this benefit as stated by Neuuman (2000).

More so, Bloomgarden and O'Meara (2007) noted three main benefits of community engagement; tangible, intangible and global benefits. They explained that intentional efforts must be geared towards achieving these benefits because they increase chances for promotion while fostering improved institutional work. Contrary to the finding of this study, some researchers have argued that community engagement is not rewarded by most institutions; these researchers' view community engagement as a hindrance to promotion because it takes away the attention of academics from more impactful activities in the domain of their career which can lead to career growth (Driscoll, 2009; Weerts \& Sandmann, 2010).

Some of the participants indicated that through their engagement in community service their knowledge expands because they don't just focus on the theoretical aspect of their specialization but are also able to link theory and practice since it is the theory they apply in solving practical problems of the community. Some of them explained that through community engagement they are able to link practical issues with theory which they teach their students in class; the professors are exposed to practical issues outside the classroom through engagement. One of the participants stated that there are some things which academics do not learn in school rather they learn on the job through community services and this he said expands his knowledge.

Another participant expressed that as a political science professor, when he engages in community service, people from the community ask him different questions related to politics so he brings back such practical questions to the class and ask his students in order to stimulate their thinking. This, he said improves his teaching method as he is able to relate practical issues from outside the classroom with theory which is taught inside the classroom. In like manner participant PK5 indicated that community engagement can expand one's knowledge thereby making one have a better understanding of issues in his/her research area and being able to proffer better solutions. This finding implies that without community engagement academics may not be able gain sufficient practical exposure which can help them link theory with practice and this create a gap between the two. It also implies that for academics to be more efficient in teaching there is need to engage in community development activities as it helps to improve teaching outcomes while expanding the knowledge of professors. According to Hesser (1995), the process of education can be improved through community engagement. Other researchers have argued that academics can also be motivated to continue engaging in community development if they see positive outcomes in terms of their teaching and learning of students (Hammond, 1994; McKay \& Rozee 2004).

Findings of O'Meara (2008, p.20) also revealed that through community engagement the knowledge horizon of academics is broadened as one of her study participants stated "Using the community as a classroom intensively and regularly has excited and opened me, as well as my students and colleagues to new methodologies and new understandings. I have learned a lot." Therefore, it is safe to conclude in this study that community engagement helps in expanding the knowledge of professors thereby improving teaching in the entire process of education. The responses of the study participants revealed that community engagement has contributed to the growth and development of their academic career significantly because community engagement broadens their knowledge and job satisfaction. They explained that they are able to have better understanding of issues related to their area of specialization through community engagement thereby having the capacity to give meaningful solutions to problems.

According to Brew (2003), community engagement of faculty members can lead to satisfaction. This finding in this study is consistent with the findings of Bloomgarden and O'Meara (2007), who found in their study that faculty members feel personally gratified when they engage in community development activities. However, the participants of their study did not link their satisfaction to how it enhances a conducive working environment for as them as it is in the case of the participants of this study. The participants in their study derived their satisfaction from the outcomes of community engagement; outcomes such as improved teaching and learning were mentioned in their study. One of the participants in the present study also expressed similar views stating that engagement in community development service gives one the experience required to link theory and practice when teaching in class; this improves the quality of teaching thereby leading to satisfaction. He explained that if he is unable to improve in his profession then he will be unsatisfied. 


\section{Implications for Human Resource Development (HRD)}

This study has a number of implications for human resource development practice and research. The study offers evidence linked to the potential benefits of developing career through community engagement in organizations. Faculty members' participation in community engagement has recognized attention in scholarly literature showcasing meaningful and credible results. In spite of this, little empirical studies have been done on this topic. This study finding provides opening confirmation to the effectiveness of community engagement in enhancing career development in academia. Hence, the current study may assist jettison existing uncertainty vis-àvis the efficacy community engagement activities in career development (Awwalu \& Najeemah, 2014; Ifedili \& Ifedili, 2015) and further facilitate the practice of community engagement in organizations, in particular the academic settings.

Also, this study finding shows a clearer portrait of developing career through community engagement practice and its finding in an organization. The experiences of the university professors in developing career through community engagement results established how the practice of community service could enhance academic career growth, expansion of knowledge and work scope through solving practical problems, and boosting job satisfaction. Henceforth, this study may assist university and academics recognize the consequence of engagement in an organization setting. Furthermore, findings from this study imply that academics and human resource development practitioners can put in practice community engagements for leadership initiatives as well as to career development. Human resource development practitioners can explore community services to train and promote leaders and managers with high work potential to the next level. Lastly, academics and Human resource development practitioners should be sure that human and social capital incentives and learning cultures (Weerts \& Hudson, 2009; Gorski \& Metha, 2016) are make available for successful implementation of the community engagement outreach within the organization.

\section{Conclusions and Suggestions for Future Research}

This study seeks to contribute to the continuing debate on human resource development through career and community development and to provide a better understanding of university community engagement from a broader perspective. The study places a much greater focus on experienced senior academics in university. Based on the findings of this study, it is also recommended that university members engage in community development work because the professors in this study stated that it helps expanding their knowledge base and enhances career growth. The participants explained that by integrating teaching, research and community work they are able to link theory with practice thereby improving their productivity in terms of teaching outcomes. This study however, can eventually lead to series of direction for further studies not to replicate, verify, or expand the findings of this study but to give a new focus and emphasis on the areas suggest- ed by this study to facilitate academic career development through community engagement practice in Nigerian universities and other West-African sub-region institution of higher learning. In addition, this study will be useful to scholars of higher education because it would add to the scanty existing literature in human resource development and community development. More significantly too, the study will be useful to university community who have the cultural mind-set that teaching and research experience as promotion criteria in academia.

Community engagement is a good strategy for career development which should be taken advantage of by higher education institutions because it is a flexible way of developing the capacity of human resources. Unlike other human resource development strategies such as workshops and trainings which require members of higher education institutions to attend time-consuming workshops that sometimes last for as little as three days and as much as one week, community engagement allows those that engage in it to do so at their convenience without much interference with other academic activities such as teaching and research which they engage in. This is one advantages of this form of human resource development strategy as it allows those that engage in it to do so while fulfilling other academic responsibilities (teaching and research).

This study is not without it limitation; it did not make comparisons between university professors from different institutions. In addition, based on the nature of this study with little number of subject matters, the results may not account to be generalizable to other population and samples. This is because the purpose of this study was to provide an in-depth partaking career experience of Nigerian professors in community engagement practice in University institution. The results however, may be useful to any population which has similar features to the sample of the current study (Merriam, 2014).

\section{ACKNOWLEDGMENT}

This work was supported by Petroleum Technology Development Fund (PTDF) Nigeria, with reference number PTDF/E/OSS/PHD/ASO/616/14.

\section{REFERENCES}

Adams, J., King, C., \& Hook, D. (2010). Global research report Africa. Leeds: Thompson Reuters.

Adekalu, S. O., Shitu, M. B., Turiman, S., Olohungbebe, L. O., \& Adio, A. A. (2017a). Facilitating Community Development through Institutional Engagements: Reflections from 2016 Nigeria IACD Conference. Journal of Resources Development and Management, 30, 132-140.

Adekalu, S. O., Krauss, S. E., Turiman, S., \& Ismail, I. A. (2017b). Exploring the Personal Philosophies of Volunteerism among Professors at a Malaysian Research University. OUSL Journal, 12(1), 91-108.

Akinyemi, S., \& Potokri, O. C. (2016). Inequitable access to the knowledge market in Nigeria: The case of university education. Industry and Higher Education, 30(6): 424-432. 
Akpan, C. P., Archibong, I. A., \& Undie, J. A. (2011). Lecturers' Access to Research Fund in Nigerian Universities: Challenges and Strategies for Improvement. Available at http://socioumane.ro/blog/analesocioumane/files/2011/04/Akpan-Archibong-Undie.pdf. Retrieved on March 27, 2016.

Awwalu, M. I., \& Najeemah, B. M.Y. (2014). University Community Engagement towards Development of Local Communities in Sokoto, Nigeria. Paper Presented at the National Conference on University-Industry-Community Engagement, Organised in University Sains Malaysia from 17-18 November.

Bako, S. (2005). Universities, Research and Development in Nigeria: Time for Paradigmatic Shift. Paper prepared for the $11^{\text {th }}$ General Assembly of CODESRIA on Rethinking African Development beyond Impasse: Towards Alternatives. Maputo, Mozambique, $6^{\text {th }}-8^{\text {th }}$ December.

Bloomgarden, A. H., \& O'meara, K. (2007). Faculty Role Integration and Community Engagement: Harmony or Cacophony? Michigan Journal of Community and Service Learning, MicSpring, 13(2), 5-18.

Boyte, H. C. (2004). Going public: Academics and public life. Dayton, $\mathrm{OH}$ : Kettering Foundation.

Boyer, E. L. (1996). "The Scholarship of Engagement," Journal of Public Service and Outreach. 1(1), 11-20.

Brew, A. (2003). Teaching and research: New relationships and their implications for inquiry-based teaching and learning in higher education. Higher Education Research \& Development, 22(1), 3-18.

Das, T. H. (1983). Qualitative research in organizational behaviour. Journal of Management Studies, 20(3), 301-314.

Driscoll, A. (2009). Carnegie's new community engagement classification: Affirming higher education's role in community. New Directions for Higher Education, 147, 5-12.

Gorski, I., \& Metha, K. (2016). Engaging Faculty across the Community Engagement Continuum. Journal of Public Scholarship in Higher Education, 6, 108-123.

Hammond, C. (1994). Integrating service and academic study: Faculty motivation and satisfaction in Michigan higher education. Michigan Journal of Community Service Learning 1(1), 21-28.

Hesser, G. (1995). Faculty assessment of student learning: Outcomes attributed to service-learning and evidence of changes in faculty attitudes about experiential education. Michigan Journal of Community Service Learning, 2, 33-42.

Idowu, B. (2014). Higher education and African development. Educational Research, 5(3), 107-115.

Ifedili, C. J., \& Ifedili, C. (2015). Management of Nigerian Universities and Community Services, European Journal of Business and Social Science, 4(9), 14-21.

Ismail, I. A. (2005). Moving on in academia: exploring the career experiences of professors at a UK university (Published PhD dissertation), University of Warwick. Available at http://wrap.warwick.ac.uk/34680/Retrieved on January 23, 2017.
Ismail, I. A., Silong, D. A., Asimiran, S. \& Hassan. Z. (2011). Development of educational leadership in Research University through community of practices among professors. Procedia - Social and Behavioral Sciences, 15, 828-832.

Janke, E. M., \& Colbeck, C. L. (2008). An exploration of the influence of public scholarship on faculty work. Journal of Higher Education Outreach and Engagement, 12(1), 31-46.

Kogan, M., \& Teichler, U. (2007). Key Challenges to the Academic Profession.UNESCO Forum for Higher Education, Research and Knowledge: Germany: International Centre for Higher Education Research (INCHERKassel),

Maimunah, I. \& Roziah, M. R. (2008). Leadership in an Academic Career: Uncovering the Experience of Women Professors. International Studies in Educational Administration, 36 (3), 87-103.

McKay, V. C., \& Rozee, P. D. (2004). Characteristics of faculty who adopt community service-learning pedagogy. Michigan Journal of Community Service-Learning 10 (2): 21-33.

Merriam, S. B. (2014). Qualitative Research: A guide to Design and Implementation. John Wilsey and Sons.

Mehta, K., Gorski, I., Liu, C., Weinstein, S., Brua, C., \& Christensen, A. (2015). Expanding engagement opportunities at a large land-grant research university: The engagement ecosystem model. Journal of Community Engagement and Scholarship, 8(2), 44-58.

Neumann, A. (2000). Toward a profession of learning: Exploring how university professors learn through their subjects through teaching. Paper presented at the meeting of the American Educational Research Association, New Orleans, LA, April, 2000.

New Economy Development Group (2002), Strategic Planning, Organizational Development and Capacity Building. Avaliable at http://www.neweconomygroup.ca/ expertise_strategic_e.html Retrieved on 17 June, 2017.

O'Meara, K. (2008), Graduate education and community engagement. New Directions for Teaching and Learning, 27-42.

O’Meara, K. (2002). Uncovering the values in faculty evaluation of service as scholarship. The Review of Higher Education, 26(1): 57-80.

Safiah, S., Mohd Taib, D., Norliah K. \& Mahadi, A. (2012). Academic Career in the Malaysian Higher Education: Becoming a Professor. Journal of Human Capital Development 5 (2), 127-140.

Terosky, A. L. (2005). Taking teaching seriously: a study of university professors and their undergraduate teaching. New Yolk: Teachers College, Columbia University.

Terosky, A. L., O’Meara, K., \& Campbell C. M. (2014). Enabling possibility: Women associate professors' sense of agency in career advancement. Journal of Diversity in Higher Education 7(1): 58-76.

Tight, M. (2002). What does it mean to be a professor? Higher Education Review, 34(2): 15-32.

Utile. T. (2008). University Autonomy and the Brain Drain Syndrome in Nigeria, Paper presented at the $3^{\text {rd }}$ Confer- 
ence of the ACU's Human Resource Management Network, 23rd-25 ${ }^{\text {th }}$ May, 2008, Trinidad \& Tobago, West Indies.

Weerts, D., \& Hudson, E. (2009). Engagement and institutional advancement. New Directions for Higher Education, 147, 65-74

Werner, J. M., \& DeSimone, R. L. (2011). Human Resource Development. New York, NY: Cengage Learning.

World Health Organization Regional Office for Europe (2002). Community participation in local health and sustainable development: Approaches and techniques. European Sustainable Development and Health Series 4 . Available at http://www.euro.who.int/document/ e78652.pdf Retrieved on April 25, 2017.

Yusuf, O. B., Adebowale, A. S., Fagbamigbe, A. F., Bamgboye, E. A., \& Oyediran, A. B. O. O. (2010). Profile of academic and senior non-teaching staff in a Nigerian university. International Journal of Educational Administration and Policy Studies, 2(7), 92-98. 